\title{
An Electron-Microscope Study of Potato Virus $X$ in Different States of Aggregation
}

\author{
BY A. KLECZKOWSKI AND H. L. NIXON \\ Rothamsted Experimental Station, Harpenden, Hertfordshire
}

\begin{abstract}
SUMMARY: Electron micrographs of potato virus $X$ show tenuous rod-shaped particles of variable length but constant width of about $10 \mathrm{~m} \mu$. Lightly shadowed rods lying along the direction of shadowing show a regular cross banding at intervals of about $10 \mathrm{~m} \mu$. Attempts to purify the virus cause the particles to aggregate and become entwined to form extensive rope- and net-like structures. This aggregation may be responsible for the loss of solubility that often accompanies purification, though similar structures are visible in micrographs of both soluble and insoluble preparations of the purifled virus. Hydrolysis by chymotrypsin yields products too small to be resolvable, and the material remaining after most of a preparation has been hydrolysed appears similar to that in unincubated preparations.
\end{abstract}

A property that distinguishes potato virus $X$ from other plant viruses that have been purified is its tendency to become insoluble when subjected to such procedures as precipitation by acids or salts, ultracentrifugation or dialysis. Insoluble preparations show little or no anisotropy of flow but they are still infective and serologically active; they can be made 'soluble' (i.e. brought into a state in which nothing sediments when liquids are centrifuged at low speeds) by incubation for a short time with trypsin or chymotrypsin, or for a longer time with borate buffer at $\mathrm{pH} \mathrm{7 \cdot 3-7 \cdot 5} \mathrm{(Bawden} \mathrm{\&} \mathrm{Kleczkowski,} \mathrm{1948).} \mathrm{It}$ seemed possible that electron microscopy might reveal some of the causes underlying these phenomena, and for this reason studies were made of the virus in various types of preparation.

\section{MATERIALS AND METHODS}

Most work has been done with strain $X^{v}$ propagated in Datura stramonium, a strain-host combination which, of those studied, gives the highest virus concentration in sap. Similar results were obtained with other strains propagated in $D$. stramonium and in other hosts such as tobacco and tomato plants. No differences were observed in the widths of particles of different strains and all showed the same tendency to pass into insoluble forms. Clarified sap formed the starting material; infected leaves were minced in a domestic meat mincer, the juice squeezed through cloth, frozen overnight, thawed, and centrifuged for 10 min. at 8000 r.p.m. The methods of purification used were those of Bawden \& Kleczkowski (1948).

Electron microscope mounts were made by placing a droplet containing about 1 part of virus in $10^{4}$ on the usual collodion-covered specimen grid, allowing it to remain in contact for about $1 \mathrm{~min}$. and then sucking away the surplus liquid by bringing an empty micropipette into contact with the liquid surface. Mounts from virus preparations containing added salts were then immediately washed by dipping in distilled water and dried by touching the 
edge of the grid on to hard filter paper. Before examination in the R.C.A. model B electron microscope the specimens were shadowed with either $1.5 \mathrm{~m} \mu$. of nickel or $1.0 \mathrm{~m} \mu$. of palladium, the thickness of the metal film being calculated for the plane of the supporting film, assuming equal spherical distribution about a point source. The shadowing was at an angle of about 12 degrees from the plane of the supporting film.

\section{RESULTS \\ Size of particles}

Pl. 1, fig. 1, shows a typical field in a shadowed preparation made from freshly prepared clarified sap containing virus particles of constant width but greatly differing lengths. The rods are sometimes associated side by side in pairs, but each individual particle is clearly distinguishable. The manner in which they curve suggests a flexibility that contrasts sharply with the apparent rigidity of the wider tobacco mosaic virus particles (Pl. 2, figs. 7, 8). Measurement of particles lying along the direction of shadowing in our sharpest micrographs gives a width of about $10 \mathrm{~m} \mu$. for virus $X$, considerably smaller than the $16 \mathrm{~m} \mu$. recorded by Takahashi \& Rawlins (1946) from measurements on unshadowed micrographs of two strains of the virus. All the strains we have examined had particles of the same width, and none of the treatments we applied affected width, but the apparent width of these very narrow particles does depend upon the sharpness of the image obtained; in Pl. 1, figs. 2, 3, for example, where it is less sharp than in Pl. 1, fig. ' 1 , the particles appear much wider.

In some of our sharpest micrographs, particles that lie along the direction of shadowing show a regular cross-banding at intervals of about $10 \mathrm{~m} \mu$. along the length. Further work with enhanced resolution will be needed before this can be interpreted with certainty, but the uniform spacing, coupled with the fact that it is only seen on particles in line with the direction of shadowing, suggest that it reflects a regularity intrinsic to the structure of the particles and is not an artefact caused by uneven deposition or subsequent migration of the shadowing metal.

\section{Effects of ageing and purification}

When infective sap is allowed to age, or when the virus is precipitated with acids or salts, the character of the electron micrographs alters strikingly. Instead of separate particles there are elongated masses which are twisted and interwoven to form rope- and net-like structures of various sizes and degrees of complexity. This type of aggregation could well explain the observed decrease in solubility and contrasts sharply with the behaviour of tobacco mosaic virus. Purification of the latter causes the particles to increase in length by joining together end to end, but electron micrographs still show the elongated rods as independent particles. The exact pattern obtained depends upon the manner in which the mount is made; when a drop of purified tobacco mosaic virus suspension is placed on the collodion membrane and allowed to dry, the particles are distributed with their long axes in random directions and largely unassociated (Pl. 2, fig. 7), unless the concentration of the original virus suspension was high enough to give a close-packed or nearly close-packed arrangement. 
When the drop is removed after a short interval by sucking with a micropipette, a mount is produced in which most of the particles lie parallel and in contact with each other over considerable areas (Pl. 2, fig. 8). Such particles are never entangled, the orientation being presumably due to flowing liquid during the removal of the drop.

With potato virus $\boldsymbol{X}$ the method of preparing the mount for electron microscopy does not affect the manner in which the particles are distributed, similar patterns being obtained whether a drop is allowed to dry undisturbed or is sucked away. The entanglement of virus $\boldsymbol{X}$ particles may occur because they are more flexible than tobacco mosaic virus, or because they are more sticky and tend to adhere more readily to each other when they come into contact. The possibility that all these aggregated structures are artefacts produced during the mounting of the specimen cannot be dismissed, but we think it more likely that they reflect differences occurring previously in the virus preparations. The structures do not occur in mounts from freshly extracted material, and they gradually increase in size and complexity as the virus is subjected to an increasing number of treatments before mounting for electron microscopy. Pl. 1, fig. 2, shows a field in a mount made from a virus preparation that had been precipitated once only with ammonium sulphate; most of the particles still remain separate, though a few have become entangled. Pl. 1, fig. 3, is from a soluble virus preparation that was precipitated five times with ammonium sulphate and once with acid. Most of the particles are interlaced to give a typical aggregate. The virus in this preparation became insoluble when dialysed, and Pl. 2, fig. 5, shows the insoluble material. There are no obvious differences from the structures to be seen in Pl. 1, fig. 3, and this we have constantly found. All insoluble virus preparations are aggregated, and electron micrographs do not suggest that they are more so than those preparations which received comparable treatment but remained soluble. Similarly, when soluble preparations are rendered insoluble by the action of ribonuclease (Bawden \& Kleczkowski, 1948), micrographs of the precipitated virus are similar to those of the unprecipitated material. So, too, when insoluble preparations are brought into solution by incubation with borate buffer or with trypsin, the micrographs reveal no apparent differences between the state of aggregation before and after treatment. This may mean that the structures are in part produced during the mounting of the specimens, or it may be that solubility is determined by slight differences in the degree of aggregation and that such slight differences are not visible in our electron micrographs.

\section{Effects of trypsin and chymotrypsin}

Trypsin and chymotrypsin affect potato virus $\boldsymbol{X}$ in several different ways. They hydrolyse the virus, leading to loss of infectivity and all characteristic properties (Bawden \& Pirie, 1936), but, depending upon the type of virus preparation used, they may also have other preliminary actions. Preparations consisting mainly of short particles become aggregated (Bawden \& Crook, 1947), whereas insoluble preparations can be brought into solution, sometimes within 
a few seconds and sometimes more slowly (Bawden \& Kleczkowski, 1948). Attempts have been made to follow these changes, but the results are not readily interpretable.

Table 1. Hydrolysis at $37^{\circ}$ of a purified preparation of potato virus $X$ by chymotrypsin

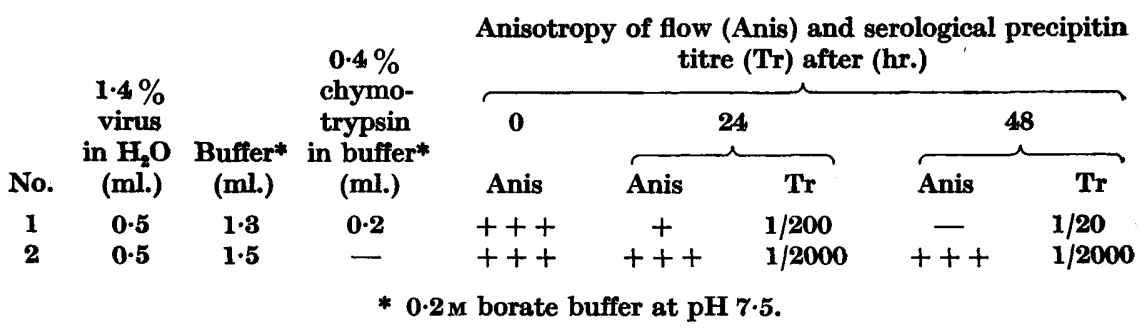

Table 2. Hydrolysis at $37^{\circ}$ of potato virus $X$ in clarified sap by chymotrypsin

\begin{tabular}{|c|c|c|c|c|c|c|c|}
\hline \multirow[b]{2}{*}{ No. } & \multirow{2}{*}{$\begin{array}{l}\text { Sap* } \\
\text { (ml.) }\end{array}$} & \multirow{2}{*}{\multicolumn{2}{|c|}{$\begin{array}{cc}0.25 \% \\
\text { chymo- } \\
\text { trypsin } \\
\text { Buffer* in buffer* } \\
\text { (ml.) } \quad \text { (ml.) }\end{array}$}} & \multicolumn{4}{|c|}{ Serological precipitin titre after (hr.) } \\
\hline & & & & $\mathbf{0}$ & $\mathbf{3}$ & 6 & $\mathbf{2 4}$ \\
\hline 1 & $\mathbf{1 . 5}$ & $\mathbf{2 \cdot 2 5}$ & $0 \cdot 75$ & $1 / 640$ & $\mathbf{1} / \mathbf{3 2 0} \dagger$ & $1 / 80 \dagger$ & $1 / 5 \ddagger$ \\
\hline 2 & 1.5 & 3.00 & - & $1 / 640$ & $1 / 640$ & $\mathbf{1} / \mathbf{3 2 0}$ & $\mathbf{1} / \mathbf{3 2 0}$ \\
\hline
\end{tabular}

* $0 \cdot 2 \mathrm{M}$ borate buffer at $\mathrm{pH} 7 \cdot 5$. The $\mathrm{pH}$ of the mixtures was slightly under $7 \cdot 0$. It was adjusted to about $7 \cdot 2$ by adding a few drops of $0 \cdot 1 \mathrm{~N}-\mathrm{HCl}$.

$\dagger$ The fluids developed a slight sheen. The appearance of the precipitate was more opaque and granular than in the control.

$\ddagger$ The fluid contained a small amount of insoluble material which was removed by centrifugation.

Table 1 shows the effects of incubating an aggregated but still soluble preparation of virus $\boldsymbol{X}$ with chymotrypsin, the hydrolysis of the virus being estimated by decreases in anisotropy of flow and precipitin titre. At intervals samples were withdrawn for making electron microscope mounts, the dilution being adjusted to keep the concentration of unhydrolysed virus in the mount approximately constant. Pl. 1, fig. 3, shows the material at the start of the experiment; after $48 \mathrm{hr}$. incubation the unhydrolysed virus, about $1 \%$ of that originally present, still showed the same aggregated structures. Bringing insoluble material into solution by short incubation with chymotrypsin also had no effect on the degree of aggregation as shown in the electron micrographs, and it seems probable that the change from insoluble to soluble state, is determined by the size of single aggregates, and can take place by the breaking of large into similar but smaller structures. The hydrolysis of a few cross-linking particles might be enough to do this.

The hydrolysis of individual particles does not seem to occur by their breaking into pieces of successively shorter lengths; instead the whole particle seems to disintegrate into fragments too small to be resolved by the electron microscope. 
We have never observed more short particles in an incubated preparation than in unincubated controls, although interpretation is difficult because of the tendency for chymotrypsin to bring about aggregation at the same time as hydrolysis. This effect is shown in Table 2 and Pl. 2, figs. 5, 6. The starting material was clarified infective sap from $D$. stramonium similar to that shown in Pl. 1, fig. 1, in its state of aggregation; after $3 \mathrm{hr}$. incubation, when about half the virus originally present had been hydrolysed, a sample withdrawn for electron microscopy showed that the remaining virus particles were partially aggregated (P1. 2, fig. 5). After $24 \mathrm{hr}$. incubation the preparation contained masses of tightly aggregated material that had become insoluble (Pl. 2, fig. 6). The control, incubated in buffer alone, was not obviously aggregated after $3 \mathrm{hr}$., but became partially so after $24 \mathrm{hr}$. incubation.

\section{REFERENCES}

Bawden, F. C. \& Crook, E. M. (1947). Some properties of potato virus $X$ in leaf extracts made in different ways. Brit. J. exp. Path. 28, 403.

Bawden, F. C. \& Kueczkowski, A. (1948). Variations in the properties of potato virus $X$ and their effects on its interactions with ribonuclease and proteolytic enzymes. J. gen. Microbiol. $2,173$.

Bawden, F. C. \& Pirie, N. W. (1936). Experiments on the chemical behaviour of potato virus $X$. Brit. J. exp. Path. 17, 64.

Takahashi, W. N. \& Rawlins, T. E. (1946). An electron microscope study of two strains of potato virus X. Amer. J. Bot. 33, 740.

\section{EXPLANATION OF PLATES}

\section{Plate 1}

Fig. 1. Potato virus $X$. Clarified infective sap. The cross-banding is visible on some rods lying along the shadowing direction. Palladium shadowed. $\times \mathbf{3 0 , 6 0 0}$.

Fig. 2. Potato virus $X$. Precipitated once with $1 / 3$ saturated ammonium sulphate. Nickel shadowed. $\times 24,700$.

Fig. 8. Potato virus $X$. Precipitated five times with $1 / 3$ saturated ammonium sulphate and then once with acid. Soluble. Nickel shadowed. $\times 28,000$.

Fig. 4. Potato virus $X$. The same virus preparation as fig. 3, mounted after dialysis, when it had become insoluble. Nickel shadowed. $\times 27,300$.

\section{Plate 2}

Fig. 5. Potato virus $X$. Clarified infective sap after $3 \mathrm{hr}$. incubation at $37^{\circ} \mathrm{C}$. with chymotrypsin in $0.2 \mathrm{M}$ borate buffer at $\mathrm{pH} 7 \cdot 2$. Palladium shadowed. $\times 23,400$.

Fig. 6. Potato virus $X$. Large aggregates of insoluble material produced by $24 \mathrm{hr}$. incubation with chymotrypsin as for fig. 5 . Palladium shadowed. $\times 31,400$.

Fig. 7. Tobacco mosaic virus. Randomly distributed particles obtained when a droplet of purified virus preparation is allowed to dry on the collodion film. Palladium shadowed. $\times \mathbf{3 6 , 6 0 0}$.

Fig. 8. Tobacco mosaic virus. Particles oriented when a droplet of the same virus preparation was removed by suction after 1 min. in contact with the collodion film. Palladium shadowed. $\times 25,300$. 
Journal of General Microbiology, Vol. 4, No. 2
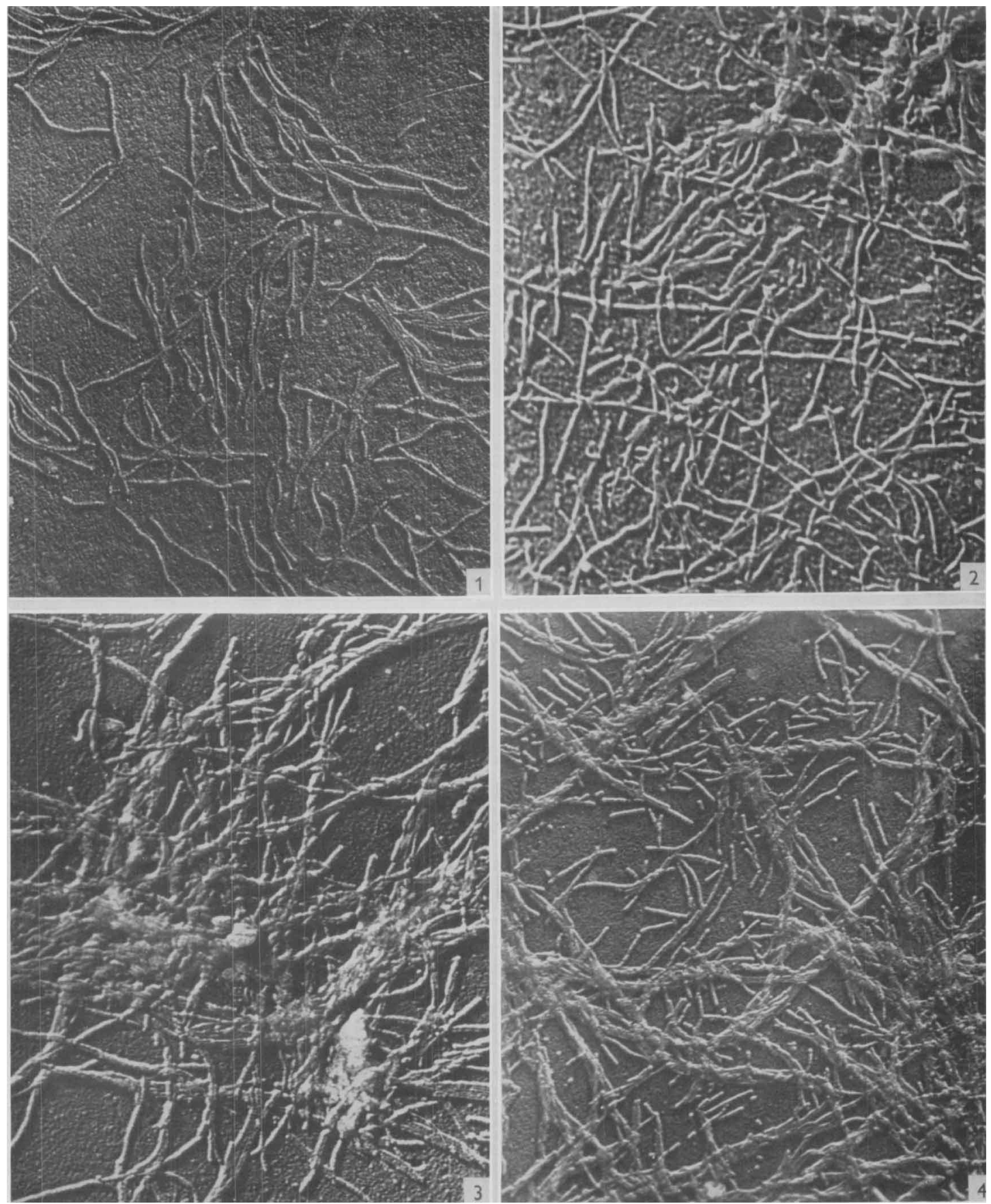

Figs. 1-4

1. Kleczkowski \& H. L. Nixon-Aggregation of potato virus $X$. Piate 1 
Journal of General Microbiology, Vol. 4, No. 2
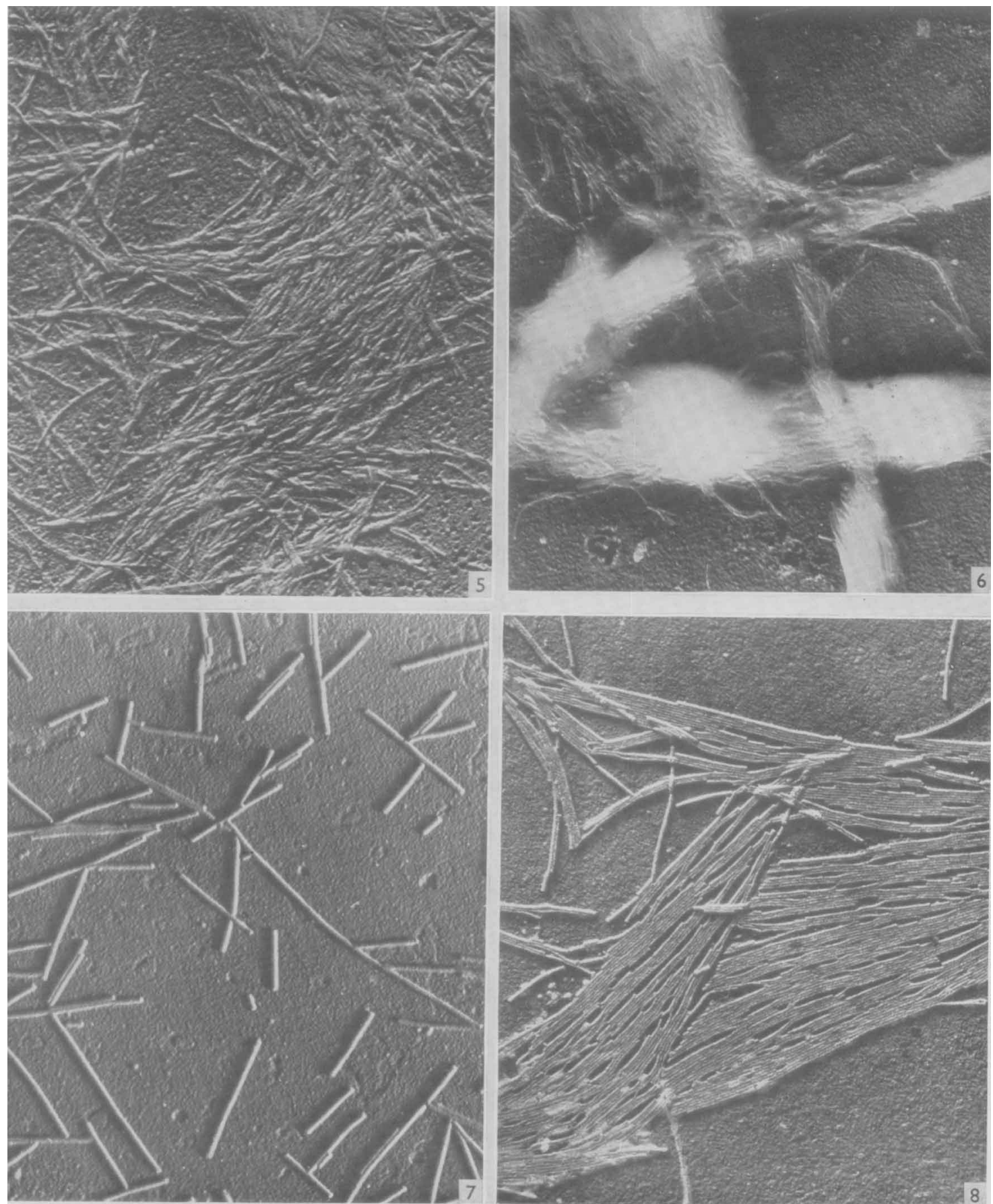

Figs. 5-8

A. Kleczkowski \& H. L. Nixon-Aggregation of potato virus $X$. Plate 2 